\title{
Digestive Enzymes in Larvae and Juveniles of Farmed Sharpsnout Seabream (Diplodus puntazzo) (Cetti, 1777)
}

\author{
Benedetto Savona*, Cecilia Tramati and Antonio Mazzola
}

University of Palermo, Department of Ecology, Palermo, Italy

\begin{abstract}
The ontogenetic development and pattern of main digestive enzyme activities (proteases, carbohydrases and lipases) were investigated in farmed sharpsnout seabream Diplodus puntazzo larvae and juveniles, during the passage from the larval stage to adult (from 21 to 277 days after hatching - DAH). Larvae showed exponential growth, thus confirming that Rotifers and Artemia nauplii are suitable preys for early feeding of D. puntazzo larvae.

Pepsin activity was low in the larvae, but it increased afterwards in relation with stomach development. In juveniles, levels of specific activity of trypsin, chymotrypsin and elastase were lower compared to that recorded in larvae. A decrease in the activity of the alkaline proteases could be related to an increase in the functionality of stomach. Qualitative and quantitative assay of glycosidases ( $\alpha$-amylase, cellulase and maltase) showed high glycosidase activity, indicating that D. puntazzo is capable of digesting carbohydrates in its diet. Levels of lipase activity in juveniles were higher than those found in larvae. Our results didn't show an inductive character of lipases, since in juveniles the activity levels were almost constant even if the fat content of compound diet varied (from $7.0 \%$ to $20 \%$ ).

The rapid changes in the digestive activities of $D$. puntazzo larvae supported the existence of well established induction and regulation digestive mechanisms. Present results also confirm that $D$. puntazzo larvae have complete digestive enzymatic equipment that increased during larval ontogeny and enable larvae to digest and absorb nutrients contained in live preys once exogenous feeding occurred. The enzymatic pattern is correlated with omnivorous feeding habits of the species. Moreover, the patterns of activity of the main digestive enzymes of D. puntazzo larvae and juveniles indicated the early functional development of their digestive system and suggested this species as a good candidate for Mediterranean aquaculture using the compound diet.
\end{abstract}

Keywords: Diplodus puntazzo, Sharpsnout seabream, larvae, juveniles, digestive enzymes, protease, amylase, maltase, cellulase, lipase.

\section{INTRODUCTION}

The current real trend in European aquaculture development is the increasing production of marine species, both molluscs and fish. The growth in aquaculture production is mainly due to the mastering of seed production techniques for European seabass (Dicentrarchus labrax) and gilthead seabream (Sparus aurata) and to the application of new farming technologies. Commercial fish culture is based mainly on intensive production, where the techniques of larvae production have been developed. Successful fish larvae culture has been based on zootechnical advances and fish nutrition and digestive capacity [1].

A major contribution to the problem of nutrition of farmed species can therefore come from study of the physiology of their digestive system. Biochemical information on digestive enzymes in the fishes constitute a contribution for the definition of nutritional protocols. In fact there are, in the different species, anatomical and physiological adaptations that justify the different dietary.

The nutritional value of a diet is closely related to the ability of an organism to digest and absorb the substance

*Address correspondence to this author at the University of Palermo, Department of Ecology, Via Archirafi, 18 - 90123 Palermo, Italy; Tel: +39.091.23862875; Fax: +39.091.6100278; E-mail: bsavona@unipa.it contained therein, and this depends on both the physicalchemical nature of the food, both from the type of enzyme activities present along the alimentary tract [2].

Much research has been conducted in the last two decades to study the digestive ability and specific nutritional requirements as well as ontogenesis of digestive enzymes and as developmental features of the digestive tract of fish larvae and juveniles as red drum Scienops ocellatus [3, 4], gilthead sea bream Sparus aurata [5,6], European sea bass Dicentrarchus labrax [7, 8], dover sole Solea solea [9], turbot Scophthalmus maximus [10-12], senegal sole Solea senegalensis [13], Japanese flounder Paralichthys olivaceus [14].

The morphology and some metabolic pathways in fish larvae are different from those of juvenile or adult fish. These differences happen throughout the larval period with the maturation of some tissues and organs, in particular with the onset, decrease or increase in activity of a wide range of digestive enzymes [15-17].

In cultured species, detailed knowledge of digestive physiology and organization during the development is fundamental, since the level of activity of some enzymes can be used as indicators of the nutritional status of the larvae [18]. Additionally, this information can help to determine the most appropriate moment for weaning, as well as the 
possibility and limitations in the employment of artificial diets.

The maturation of the digestive tract in fish can be altered by diet composition. Attempts have been made to substitute partially or completely compound diets for live prey in various larval stages $[19,20]$. Total substitution of live prey by a compound diet led to proper development and good growth and survival in European sea bass reared in the laboratory [21].

Such information may be useful in the selection of feed ingredients, particularly for newly species, such as sharpsnout seabream (Diplodus puntazzo), a sparid considered one of the most attractive candidates for diversification of Mediterranean aquaculture [22-24].

D. puntazzo is a demersal sparid teleost inhabiting rocky bottoms and sea grass beds at depths up to $150 \mathrm{~m}$ and also distributed along the Mediterranean Sea, rarely Black Sea, European and African coasts of the Atlantic Ocean, from Bay of Biscay to Sierra Leone, the Canary Islands and Cape Verde. It is an omnivore feeding on seaweeds, worms, molluscs and shrimps [25]. In the Mediterranean Sea, spawning takes place during September-November, when water temperature ranges between 20 and $23{ }^{\circ} \mathrm{C}[22,26]$. These fish are considered to have very tasty meat and are generally appreciated.

In the Mediterranean his breeding was carried out in recent years by referring to the farming technologies and nutrition protocols developed for European seabass and gilthead seabream. Increasing knowledge of the digestive enzymes activities and nutritional requirements of the larvae of new candidate species for aquaculture will aid in the development of optimal feeding protocols and greatly improve production under hatchery conditions.

Recent studies with $D$. puntazzo have been focused on macronutrient selection [27], sensory evaluation [28], feeding rate, dietary, and food intake [29], and polyculture [30] in usual juvenile and/or adult fish.

Several studies have been conducted on the digestive potential of juveniles and adults of this species [31-33]. These studies reported the main digestive enzyme activities (as proteases, carbohydrases and lipases) present along the alimentary tract [31-33] and the changes in the digestive activities at specific time intervals after feeding [32], with the aim of improving the knowledge of its nutritional physiology and digestive capabilities.

Suzer et al. [34] report data on the ontogenetic development and pattern of digestive enzyme activities of $D$. puntazzo larvae fed on live prey and compound microdiet until the end of weaning at 50 days after hatching.

The objective of this study was to evaluate, by use of biochemical techniques, the ontogenetic development and pattern of main digestive enzyme activities of $D$. puntazzo larvae and juveniles fed on live prey and compound diet from 21 to 277 days after hatching (DAH), as a contribution to the formulation of an appropriate nutritional protocol for larvae and juveniles of this species.

\section{MATERIALS AND METHODOLOGY}

\section{Experimental Design and Samples Collection}

Eggs and larvae of Diplodus puntazzo were obtained by artificial reproduction of broodstock kept at the hatchery in a commercial Sicilian fish farm. Deposition occurred spontaneously and without the modification of the photoperiod. At the hatching the environmental parameters of the tanks were: temperature $=20{ }^{\circ} \mathrm{C}$, salinity $=37$, dissolved oxygen $=8.0$ $\mathrm{mg} \mathrm{l}^{-1}, \mathrm{pH}=7.8$.

During embryonic development the environmental parameters have remained unchanged and were performed six changes of water in $24 \mathrm{~h}$. The initial stocking density of larvae was 140 larvae $1^{-1}$. Up to 50 days the animals were kept in placed inside tanks of $4 \mathrm{~m}^{3}$, while at 75 days were transferred to placed outside tanks of $40 \mathrm{~m}^{3}$ after selection.

The larvae were fed enriched rotifers (Brachionus plicatilis) from days 0 to 16 , Artemia sp. nauplii until 30 days and extruded compound diet from 31 days. The animals were not treated with antibiotics or the tanks treated with antifouling substances. In Table $\mathbf{1}$ are reported the main parameters of rearing.

Samples of larvae and juveniles were collected at 21, 31, 42, 68, 100, 131, 172 and 277 DAH. Sampling was carried out 3 hours after the first daily administration of food.

Total length (TL) and wet body weight (BW) of 30 specimens group ${ }^{-1}$ was measured each time after removing water with filter paper, using a fish measuring board and an analytical balance, respectively. Specific growth rate was calculated by formulae SGR $=100$ (Ln FBW $-\mathrm{Ln} \mathrm{IBW)} \mathrm{/} \Delta \mathrm{t}$, with IBW, FBW: initial, final body weight of fish $(\mathrm{mg}), \Delta \mathrm{t}$ : time interval (day).

Larvae $(21,31$ and $42 \mathrm{DAH})$ were grouped in pool [16, $34,35]$ (whose number varied between 250 and 120, depending on larvae size) $(n=3)$, immediately frozen in liquid nitrogen and transferred to $-80{ }^{\circ} \mathrm{C}$ for storage. The juveniles $(68,100,131,172,277 \mathrm{DAH})$ were individually frozen in liquid nitrogen and transferred to $-80{ }^{\circ} \mathrm{C}$ for storage.

After partial thawing each pool of larvae $(n=3)(21,31$ and $42 \mathrm{DAH}$ ) was weighed, homogenized for 3 minutes in an Ultra-Turrax homogenizer with 2,5 times its weight of ice-cold Milli-Q water to give 1:2,5 homogenate.

After partial thawing the juveniles $(68,100,131,172$ and $277 \mathrm{DAH})$ were dissected and the entire gut was removed [8, 9]; tissues from each group were pooled (the number varied between 42 and 10 , depending on size) $(n=3)$. Each pool was weighed, homogenized for 3 minutes in an Ultra-Turrax homogenizer with 10 times its weight of ice-cold Milli-Q water to give 1:10 homogenate.

The homogenates of larvae and juveniles were centrifuged at $25000 \mathrm{x} \mathrm{g}$ for 40 minutes at $2{ }^{\circ} \mathrm{C}$ in a refrigerated ultracentrifuge. The precipitant was discarded and the clear supernatant was used as crude enzymes extract without further purification. On each supernatant was determined protein concentration by the method proposed by Bradford [36], using bovine serum albumin (BSA) as standard. 


\section{Assays of Enzyme Activities}

The pepsin activity was determined using the method of Anson [37] modified according to Rick [38], with bovine haemoglobin as the substrate. The reaction mixture consisted of $0.5 \mathrm{ml}$ of bovine haemoglobin $(2 \%$ in $0.06 \mathrm{~N} \mathrm{HCl} ; \mathrm{pH}$ 2.00 ) and $0.1 \mathrm{ml}$ of the enzyme extract. The mixture was incubated for 10 minutes at $35.5{ }^{\circ} \mathrm{C}$. The enzyme extract in the control was added after incubation. At the end of incubation, $1.0 \mathrm{ml}$ of $5 \%$ trichloroacetic acid was added in both the test and control and the mixture was centrifuged at $3500 \mathrm{rpm}$ for 10 minutes. Absorbance of supernatant was determined at $280 \mathrm{~nm}$ using a UV-VIS spectrophotometer (Shimadzu Corporation). Specific pepsin activity is reported as $U=\mu \mathrm{g}$ of tyrosine $\mathrm{min}^{-1} \mathrm{mg}^{-1}$ of protein present in the enzyme extract tested, after preparation of an appropriate calibration curve using L-tyrosine as standard.

The trypsin activity was determined using the method of Hummel [39] modified by Rick [40], with TAME (ptoluenesulfonyl-L-arginine methyl ester) as the substrate. The reaction mixture consisted of $0.05 \mathrm{ml}$ of enzyme extract and $0.15 \mathrm{ml}$ of $10.0 \mathrm{mM}$ TAME in $1.3 \mathrm{ml}$ of $46.0 \mathrm{mM}$ Tris buffer at $\mathrm{pH} 8.10$ with $11.5 \mathrm{mM} \mathrm{CaCl}_{2}$. The reaction started with the addition of enzyme extract to the mixture of TAME solution and buffer. The hydrolysis of TAME was measured as change in absorbance at $247 \mathrm{~nm}$ during $3 \mathrm{~min}$ at $25.0^{\circ} \mathrm{C}$. Specific trypsin activity is reported as $\mathrm{U}=0.001 \Delta \mathrm{Abs}_{247}$ $\mathrm{min}^{-1} \mathrm{mg}^{-1}$ of protein present in the enzyme extract tested.

The chymotrypsin activity was determined using the method of Hummel [39] described by Rick [41], with BTEE (N-benzoyl-L-tyrosine ethyl ester) as the substrate. The reaction mixture consisted of $0.05 \mathrm{ml}$ of enzyme extract and $0.70 \mathrm{ml}$ of BTEE $(80.0 \mathrm{mM}$ in $50 \%$ methanol) in $0.75 \mathrm{ml}$ of $80.0 \mathrm{mM}$ Tris buffer at $\mathrm{pH} 7.80$ with $0.1 \mathrm{M} \mathrm{CaCl}_{2}$. The reaction started with the addition of enzyme extract to the mixture of BTEE solution and buffer. The hydrolysis of BTEE was measured as change in absorbance at $256 \mathrm{~nm}$ during $3 \mathrm{~min}$ at $25.0{ }^{\circ} \mathrm{C}$. Specific chymotrypsin activity is reported as $\mathrm{U}=0.001 \Delta \mathrm{Abs}_{256} \mathrm{~min}^{-1} \mathrm{mg}^{-1}$ of protein present in the enzyme extract tested.

The elastase activity was determined using the method of Sachar et al. [42] with elastin-orcein as the substrate. The reaction mixture consisted of $0.10 \mathrm{ml}$ of enzyme extract and $10.0 \mathrm{mg}$ elastin-orcein in $1.0 \mathrm{ml}$ of $0.1 \mathrm{M}$ glycine- $\mathrm{NaOH}$ buffer at $\mathrm{pH}$ 10.0. The mixture was incubated for 60 minutes at $37.0^{\circ} \mathrm{C}$. The enzyme extract was added to the control after incubation. At the end of incubation the mixture was centrifuged at $3500 \mathrm{rpm}$ for 10 minutes. Absorbance of supernatant, which presented a colour due to the release of orcein from elastin-orcein, was determined at $590 \mathrm{~nm}$. Specific elastase activity is reported as $U=\mu \mathrm{g}$ of orcein $\mathrm{min}^{-1} \mathrm{mg}^{-1}$ of protein present in the enzyme extract tested, after preparation of an appropriate calibration curve using orcein as the standard.

The $\alpha$-Amylase activity was determined using the method of Bernfeld [43] described by Rick [44], with soluble starch as the substrate. The reaction mixture consisted of $0.05 \mathrm{ml}$ of enzyme extract, $1.0 \mathrm{ml}$ solution of soluble starch ( $1 \%$ in phosphate buffer $\mathrm{pH} 6.9$ ) and $1.0 \mathrm{ml}$ of $20 \mathrm{mM}$ phosphate buffer at $\mathrm{pH} 6.9$ with $10 \mathrm{mM} \mathrm{NaCl}$. The mixture was incubated for 10 minutes at $25.0{ }^{\circ} \mathrm{C}$. The enzyme extract was added to the control after incubation. At the end of incubation $2.0 \mathrm{ml}$ of dinitrosalicylate (DNS) reagent (1\% DNS; $30 \%$ sodium potassium tartrate) was added and the mixture was placed in boiling water for 5 minutes. After cooling to room temperature for 30 minutes, absorbance of the mixture, which presented a colour due to the release of free reducing sugars by $\alpha$-amylase, was determined at 540 $\mathrm{nm}$. Specific $\alpha$-Amylase activity is reported as $U=\mu \mathrm{g}$ of maltose $\mathrm{min}^{-1} \mathrm{mg}^{-1}$ of protein present in the enzyme extract tested, after preparation of an appropriate calibration curve using maltose as the standard.

The maltase ( $\alpha$-glycosidase) activity was determined using the method of Dahlqvist [45], with maltose monohydrate as the substrate. The reaction mixture consisted of $32 \mu \mathrm{l}$ of enzyme extract and $32 \mu \mathrm{l}$ of $56 \mathrm{mM}$ maltose monohydrate in $0.1 \mathrm{M}$ maleate buffer at $\mathrm{pH}$ 6.0. The mixture was incubated for 60 minutes at $37.0^{\circ} \mathrm{C}$. The enzyme extract was added to the control after incubation. At the end of incubation $936 \mu \mathrm{l}$ of reagent for glucose $(9.6 \mathrm{mg}$ of glucose oxidase - Type II-S from Aspergillus niger, 18800 units per $\mathrm{mg}$ of solid - in $100 \mathrm{ml}$ of $0.5 \mathrm{M}$ Tris buffer at $\mathrm{pH} 7.0$ ), 1.0 $\mathrm{ml}$ of o-dianisidine solution $\left(10 \mathrm{mg} \mathrm{ml}^{-1}\right.$ in $95 \%$ ethanol), $1.0 \mathrm{ml}$ of TritonX-100 solution $(20 \% \mathrm{w} / \mathrm{w}$ in $95 \%$ ethanol) and $0.5 \mathrm{ml}$ of $1 \mathrm{mg} \mathrm{ml}^{-1}$ horseradish peroxidase (65 units of purpurogallin per $\mathrm{mg}$ of solid) solution were added and the mixture was incubated for 60 minutes at $37^{\circ} \mathrm{C}$. After cooling in ice-cold water, absorbance of the mixture, which presented a colour due to the release of glucose by maltase, its subsequent oxidation by glucose oxidase with release of gluconic acid and hydrogen peroxide and subsequent reaction between peroxide and o-dianisidine by peroxidase with release of the dye dianisidine, was determined at $450 \mathrm{~nm}$. Specific maltase activity is reported as $U=\mu \mathrm{g}$ of glucose $\mathrm{min}^{-1} \mathrm{mg}^{-1}$ of protein present in the enzyme extract tested, after preparation of an appropriate calibration curve using glucose as the standard.

The cellulase ( $\beta$-glycosidase) activity was determined using the method of Pettersson and Porath [46], with carboxymethylcellulose as the substrate. The reaction mixture consisted of $0.1 \mathrm{ml}$ of enzyme extract and $1.0 \mathrm{ml}$ of $10 \mathrm{~g} \mathrm{l}^{-1}$ carboxymethylcellulose in $0.1 \mathrm{M}$ sodium-acetate buffer at $\mathrm{pH}$ 5.0. The mixture was incubated for 10 minutes at $40.0^{\circ} \mathrm{C}$. The enzyme extract was added to the control after incubation. At the end of incubation $1.5 \mathrm{ml}$ of dinitrosalicylate (DNS) reagent (10 $\mathrm{g}$ of DNS, $2 \mathrm{~g}$ of phenol, $0.5 \mathrm{~g}$ of sodium sulphite and $200 \mathrm{~g}$ of sodium potassium tartrate in 0.51 of 2 $\% \mathrm{NaOH}$ ) was added and the mixture was placed in boiling water for 15 minutes. After cooling to room temperature for 30 minutes, absorbance of the mixture, which presented a colour due to the release by cellulase of reducing hemiacetals groups, was determined at $640 \mathrm{~nm}$. Specific cellulase activity is reported as $U=\mu \mathrm{g}$ of glucose $\mathrm{min}^{-1} \mathrm{mg}^{-1}$ of protein present in the enzyme extract tested, after preparation of an appropriate calibration curve using glucose as the standard.

The lipase (triacylglycerol acylhydrolase) activity was determined using the method of Tietz and Fiereck [47], with olive oil as the substrate. The reaction mixture consisted of $0.5 \mathrm{ml}$ of enzyme extract, $5.0 \mathrm{ml}$ of olive oil emulsion (obtained by mixing in an ultrasonic bath at $2.0{ }^{\circ} \mathrm{C} 0.2 \mathrm{~g}$ of sodium benzoate, $7.0 \mathrm{~g}$ of arabic gum, $100 \mathrm{ml}$ of demine- 
Table 1. Main Parameters of Rearing and Composition of the Compound Diet

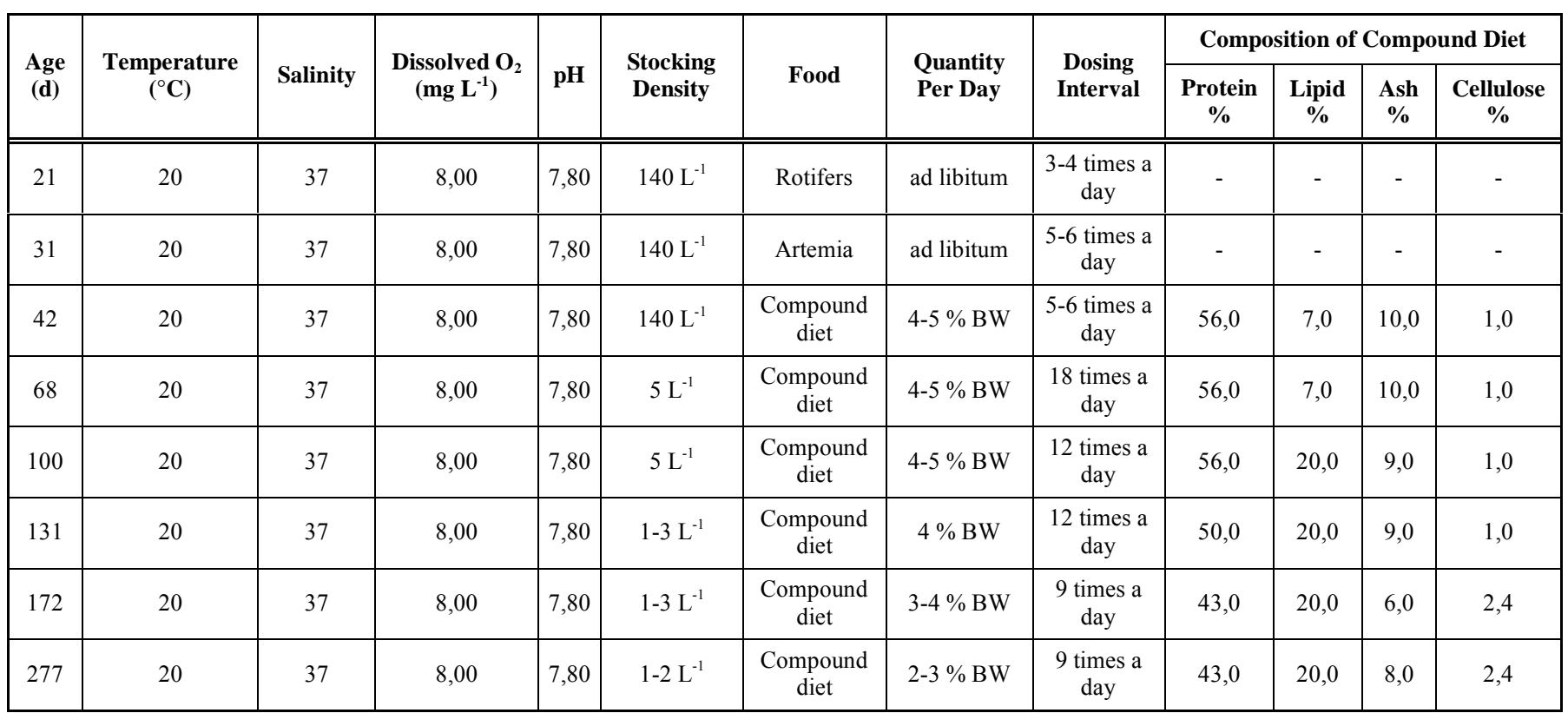

ralised water and $100 \mathrm{ml}$ of olive oil) and $1.25 \mathrm{ml}$ of $0.2 \mathrm{M}$ Tris buffer at $\mathrm{pH} 8.0$.

The mixture was incubated for 2 hours at $37.0{ }^{\circ} \mathrm{C}$. The enzyme extract was added to the control after incubation. At the end of incubation $1.5 \mathrm{ml}$ of $95 \%$ ethanol was added. Fatty acids liberated during the reaction were titrated with $0.05 \mathrm{~N} \mathrm{NaOH}$ until $\mathrm{pH}$ 10.5. Specific lipase activity is reported as $\mathrm{U}=\mu \mathrm{l}$ of $0.05 \mathrm{~N} \mathrm{NaOH} \mathrm{mg}{ }^{-1}$ of protein present in the enzyme extract tested.

\section{Statistical Analysis}

Results are given as mean \pm S.D. $(n=3$ for enzymes; $n=$ 30 for total length and body weight of larvae and juveniles). A one-way analysis of variance (ANOVA) was used (Underwood [48]) to test the null-hypothesis that there weren't differences between enzyme activities and days after hatching. Homogeneity of variances was tested using Cochran's test prior to the ANOVA and the appropriate means were compared using Student-Newman-Keuls (SNK) tests when significant differences were detected (Underwood [48]). The GMAV 5.0 statistical package (University of Sidney, Australia) was used to perform ANOVA.

\section{RESULTS}

Growth rate of $D$. puntazzo larvae and juveniles during the period of study is described in Fig. (1). From $21 \mathrm{DAH}$ total length gradually is increased and sharp increase in this parameter was observed from 42 DAH. Also, weight gain presented two phases. A first increase was observed from 31 DAH and then kept on gradually rising until 68 DAH. A second increase was detected from 100 DAH. Specific growth rate averaged $6.9 \% \mathrm{~d}^{-1}$.

The specific activities of digestive enzymes are presented in Figs. (1-8). Results are represented in chronological order, beginning with larval development and concluding with patterns of enzyme activity in juveniles.

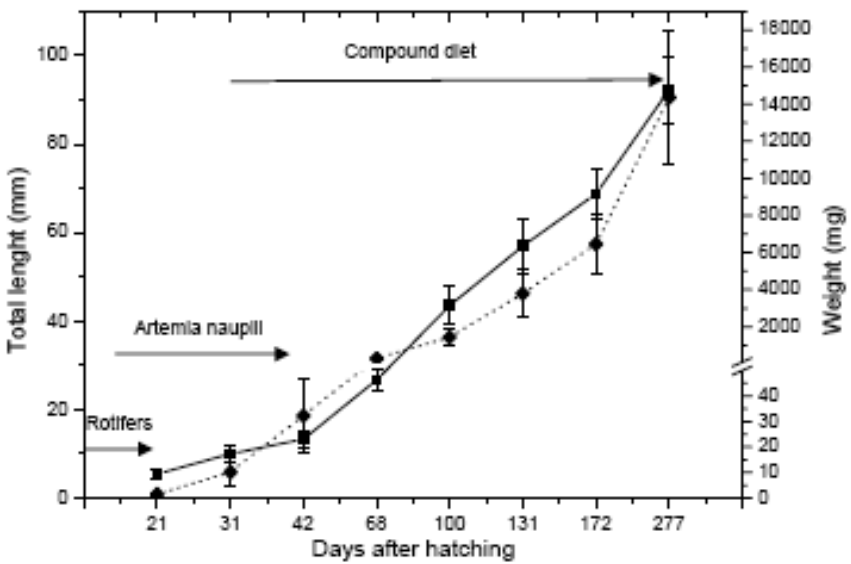

Fig. (1). Growth of $D$. puntazzo larvae and juveniles: total length (solid line); weight (dashed line). Values are means $\pm \mathrm{SD}(n=30)$. Feeding regime was summarized by arrows.

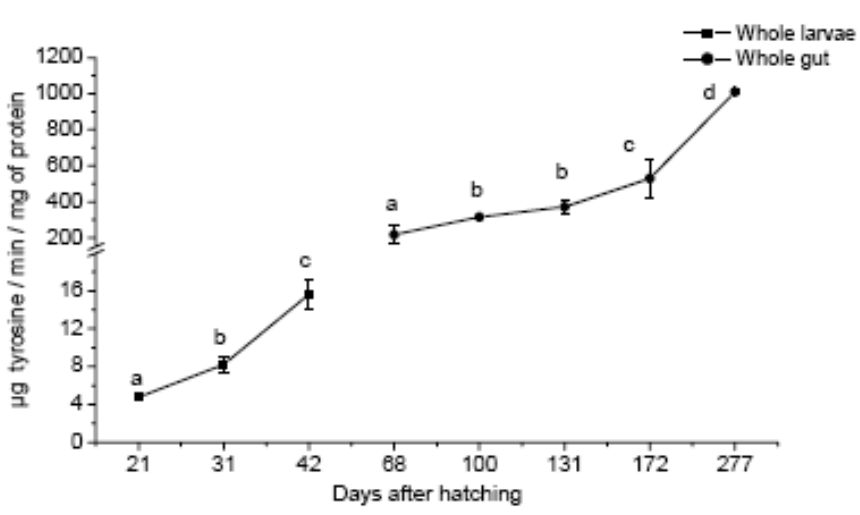

Fig. (2). Specific pepsin activity in D. puntazzo larvae and juveniles. Values are means $\pm \mathrm{SD}(n=3)$. Mean values of enzyme activity between days after hatching with a different superscript letter are significantly different $(\mathrm{P}<0.05)$. 
Pepsin specific activity shows an upward trend over time. The levels measured in the larvae are significantly different from $21 \mathrm{DAH}(4.74 \pm 0.18 \mathrm{U})$ to $42 \mathrm{DAH}(15.62 \pm 1.66 \mathrm{U})$ related with stomach development. Levels of this enzyme in juveniles show a rising trend increasing from younger to older (Fig. 2).

The levels of trypsin specific activity detected at $21 \mathrm{DAH}$ $(99.47 \pm 18.58 \mathrm{U})$ were similar to those measured in the larvae of $31 \mathrm{DAH}(136.65 \pm 24.16 \mathrm{U})$ while an increase was recorded at $42 \mathrm{DAH}(886.55 \pm 331.02 \mathrm{U})$; in the juveniles this trend remains up to size of $172 \mathrm{DAH}$ in which was determined the highest tryptic activity $(1966.79 \pm 754.97 \mathrm{U})$. After this date were observed a decrease of specific activity of trypsin until end of experiment (Fig. 3).

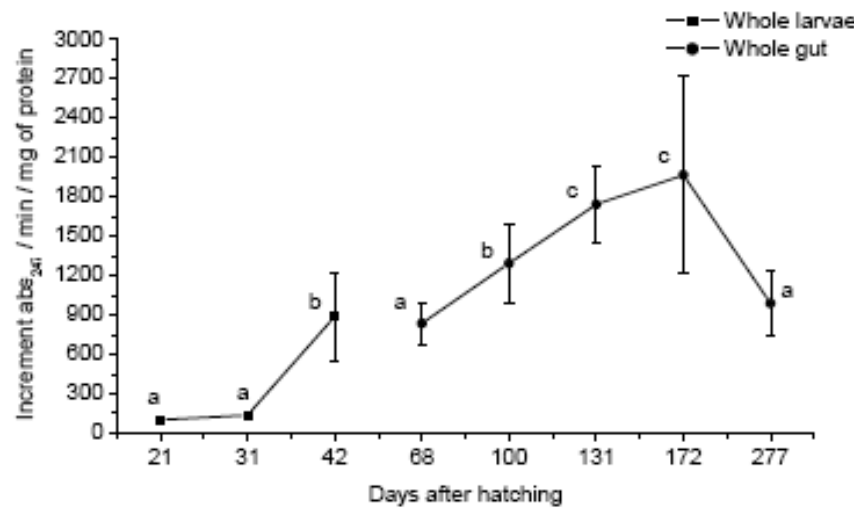

Fig. (3). Specific trypsin activity in D. puntazzo larvae and juveniles. Values are means $\pm \operatorname{SD}(n=3)$. Mean values of enzyme activity between days after hatching with a different superscript letter are significantly different $(\mathrm{P}<0.05)$.

The levels of chymotrypsin specific activity show an increase from $21 \mathrm{DAH}(713.21 \pm 805.18 \mathrm{U})$ to $42 \mathrm{DAH}$ $(1468.91 \pm 164.21 \mathrm{U})$. The levels of this enzyme measured in the intestine of juveniles show a decreasing trend from 68 $\mathrm{DAH}(1196.06 \pm 75.94 \mathrm{U})$ to $100 \mathrm{DAH}(817.22 \pm 160.52 \mathrm{U})$ and subsequently an increase until 277 DAH (1675.20 \pm $72.23 \mathrm{U}$ ) (Fig. 4).

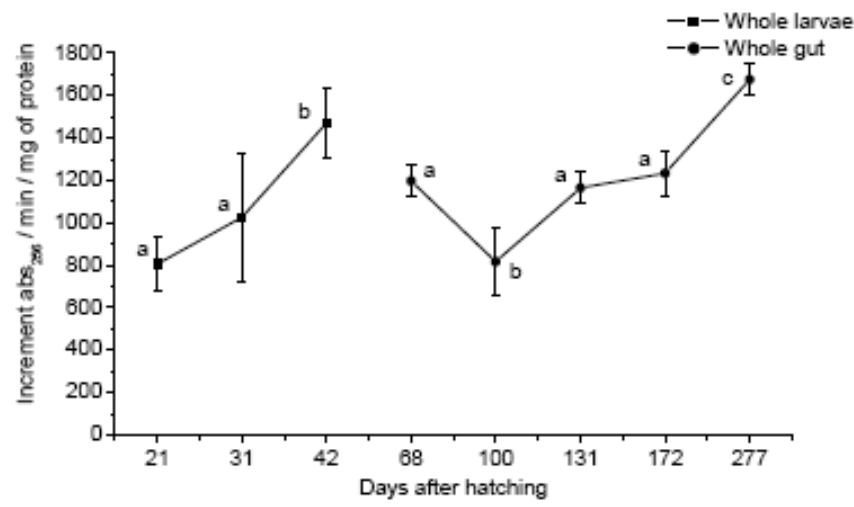

Fig. (4). Specific chymotrypsin activity in D. puntazzo larvae and juveniles. Values are means $\pm \operatorname{SD}(n=3)$. Mean values of enzyme activity between days after hatching with a different superscript letter are significantly different $(\mathrm{P}<0.05)$.

The specific activity of elastase shows a significant increase in the larvae from $21 \mathrm{DAH}(0.57 \pm 0.05 \mathrm{U})$ to 42 $\mathrm{DAH}(1.41 \pm 0.01 \mathrm{U})$. The levels of this enzyme measured in the intestine of juveniles present a maximum at $68 \mathrm{DAH}$ $(4.26 \pm 0.10 \mathrm{U})$ and subsequently a significant decrease until 277 DHA (2.51 $\pm 0.07 \mathrm{U}$ ) (Fig. 5).

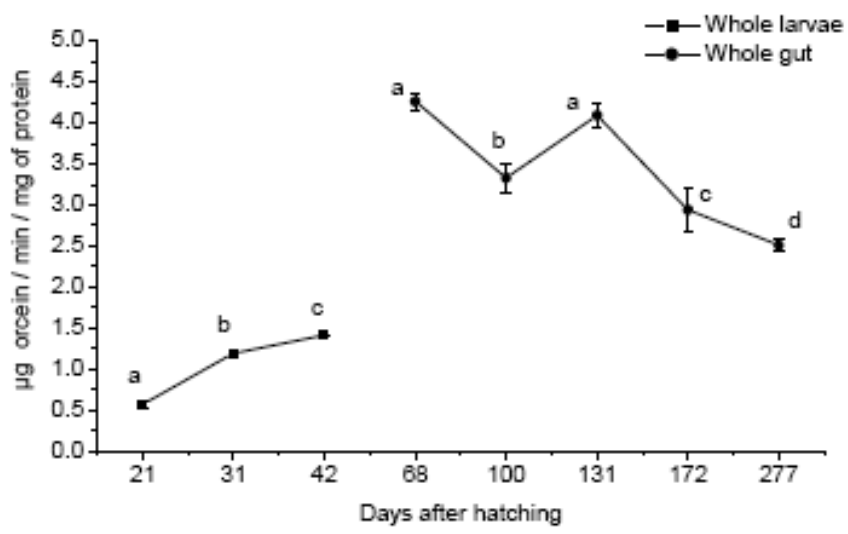

Fig. (5). Specific elastase activity in D. puntazzo larvae and juveniles. Values are means $\pm \operatorname{SD}(n=3)$. Mean values of enzyme activity between days after hatching with a different superscript letter are significantly different $(\mathrm{P}<0.05)$.

$\alpha$-Amylase specific activity increased during the first part of the experiment until 131 DAH $(637.27 \pm 12.50 \mathrm{U})$. Afterwards, slight decreases were measured to $172 \mathrm{DAH}$ $(592.36 \pm 10.80 \mathrm{U})$ but a significant decrease were found from this date until $277 \mathrm{DAH}(434.44 \pm 18.00 \mathrm{U})$. Activity of $\alpha$-Amylase demonstrated a profile of variation similar that of trypsin (Fig. 6).

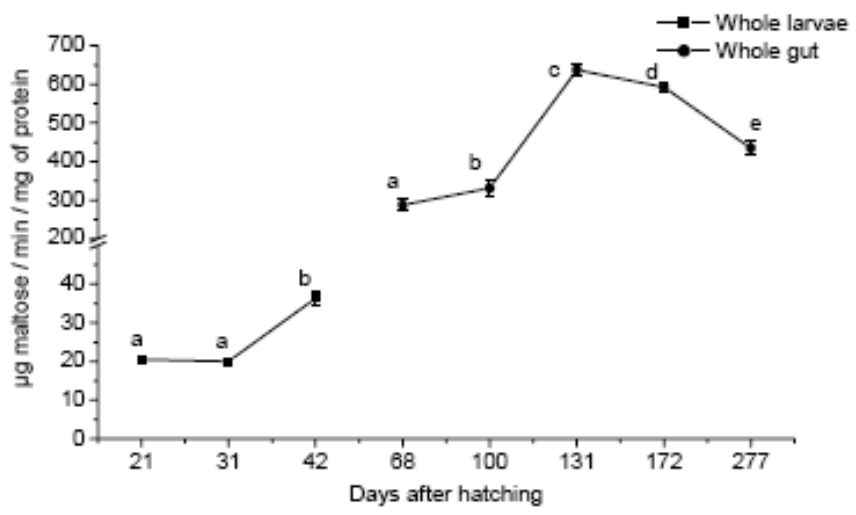

Fig. (6). Specific $\alpha$-Amylase activity in D. puntazzo larvae and juveniles. Values are means $\pm \mathrm{SD}(n=3)$. Mean values of enzyme activity between days after hatching with a different superscript letter are significantly different $(\mathrm{P}<0.05)$.

Maltase specific activity shows an upward trend over time. The levels measured in the larvae are significantly different from $21 \mathrm{DAH}(0.49 \pm 0.01 \mathrm{U})$ to $42 \mathrm{DAH}(3.16 \pm$ $0.16 \mathrm{U})$. Levels of this enzyme in juveniles show a rising trend increasing from younger to older, reaching at $277 \mathrm{DAH}$ a value of $59.36 \pm 2.66 \mathrm{U}$ (Fig. 7).

The specific activity of cellulase shows maximum levels in the larvae of smaller sizes $(29.43 \pm 0.41 \mathrm{U}$ at $21 \mathrm{DAH}$ and $29.08 \pm 0.30 \mathrm{U}$ at $31 \mathrm{DAH})$, then it shows a significant decrease at $42 \mathrm{DAH}(13.70 \pm 0.42 \mathrm{U})$. In juveniles the levels of the enzyme are lower than those recorded in the larvae and show a pattern almost constant over time $(14.21 \pm 0.38$ $\mathrm{U}$ at $68 \mathrm{DAH}$ and $20.68 \pm 0.44 \mathrm{U}$ at $277 \mathrm{DAH}$ ) (Fig. 8). 


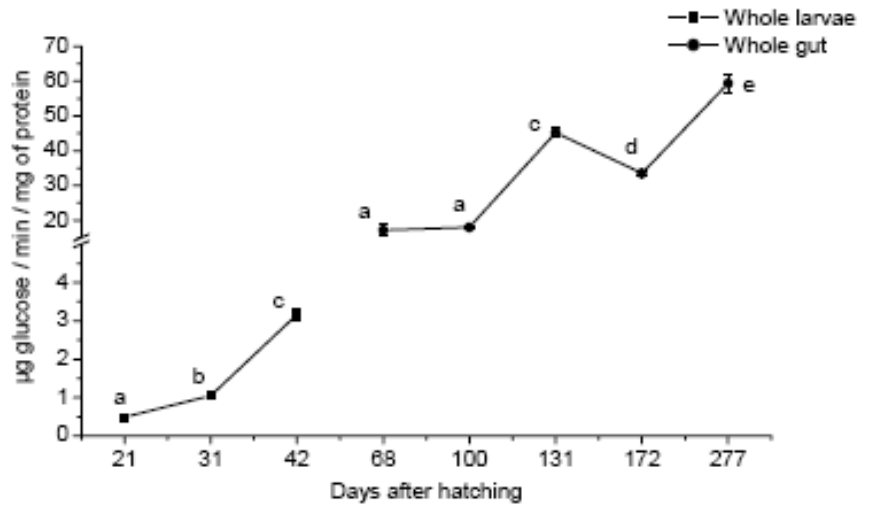

Fig. (7). Specific maltase activity in D. puntazzo larvae and juveniles. Values are means $\pm \mathrm{SD}(\mathrm{n}=3)$. Mean values of enzyme activity between days after hatching with a different superscript letter are significantly different $(\mathrm{P}<0.05)$.

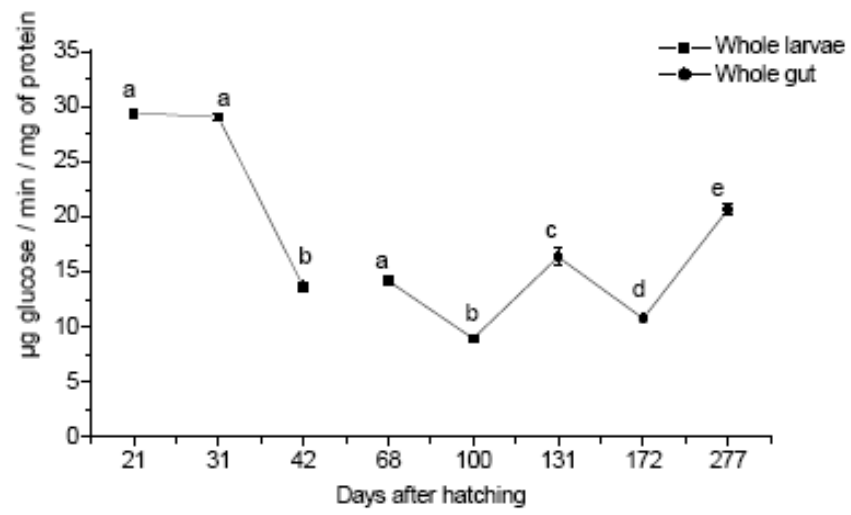

Fig. (8). Specific cellulase activity in D. puntazzo larvae and juveniles. Values are means \pm SD $(n=3)$. Mean values of enzyme activity between days after hatching with a different superscript letter are significantly different $(\mathrm{P}<0.05)$.

The specific activity of lipase shows a significant increase in the larvae from $21 \mathrm{DAH}(20.80 \pm 0.78 \mathrm{U})$ until $42 \mathrm{DAH}(35.95 \pm 0.71 \mathrm{U})$. The levels of this enzyme measured in the intestine of juveniles present, however, a significant decrease from $68 \mathrm{DAH}(96.66 \pm 4.14 \mathrm{U})$ to 131

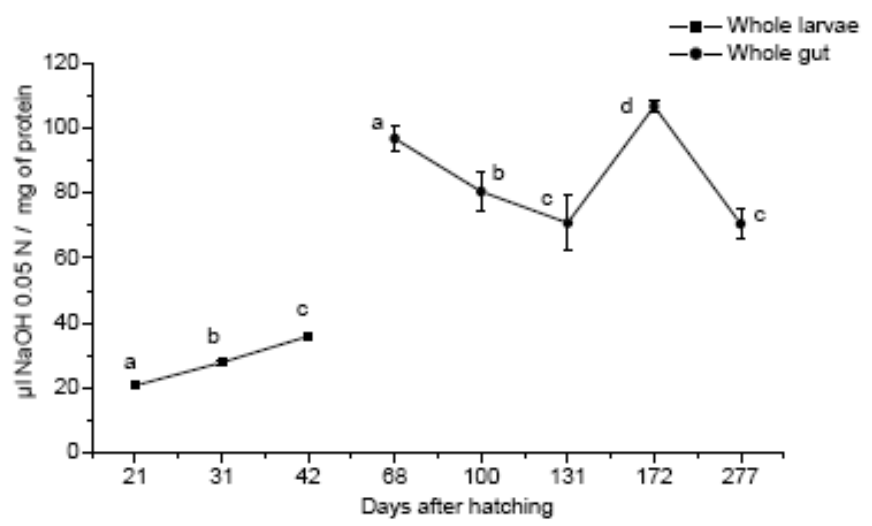

Fig. (9). Specific lipase activity in D. puntazzo larvae and juveniles. Values are means $\pm \mathrm{SD}(\mathrm{n}=3)$. Mean values of enzyme activity between days after hatching with a different superscript letter are significantly different $(\mathrm{P}<0.05)$.
DAH $(70.75 \pm 8.34 \mathrm{U})$. After this date, specific activity of lipase fluctuated until end of experiment reaching a value of $70.48 \pm 4.33 \mathrm{U}$ at $277 \mathrm{DAH}$. Activity of Lipase demonstrated a profile of variation similar that of elastase (Fig. 9).

\section{DISCUSSION}

Larvae showed exponential growth and relatively similar with previous studies on this species, thus confirming that Rotifers and Artemia nauplii are suitable preys for early feeding of Diplodus puntazzo larvae. While Boglione et al. [23] and Suzer et al. [34] estimated that total length of larvae reached about $12 \mathrm{~mm}$, Papandroulakis et al. [24] recorded that this parameter measured about $16 \mathrm{~mm}$ on day 40 . Suzer et al. [34] calculated an SGR as $10.74 \% \mathrm{~d}^{-1}$ and $5.9 \% \mathrm{~d}^{-1}$ on day 40 and 50 respectively. In this study total length measured about $13 \mathrm{~mm}$ on day 42 and SGR was calculated as $10.56 \% \mathrm{~d}^{-1}$ and $8.57 \% \mathrm{~d}^{-1}$ on day 42 and 68 respectively.

The alimentary canal of many marine fish undergoes significant changes in the transition from larvae to juveniles and adults; in larvae the alimentary canal is less differentiated than adults, both physiologically and morphologically [49-51] and that can substantially influence larval survival under culture conditions.

Early detection of digestive enzymes has been reported for several species of fish larvae [5, 10, 17, 52-54]. Enzymes related to metabolism (digestion, absorption and transport) of proteins, lipids and carbohydrates from the egg and yolk reserves have been detected following fertilization and immediately after hatching [55-58].

However, the activity of digestive enzymes in fish is low after hatching and is often not detected at the early larval stages $[49,59,60]$. In nature this deficiency is remedied by the contribution of exogenous enzymes contained in the prey, which supplement the enzyme profile of the larvae.

Some authors have suggested that larvae utilize enzymes from their prey to facilitate the process of digestion until the larval alimentary system is fully differentiated and developed [61-64]. The authors estimated that $40-80 \%$ of the enzymatic activity was donated by the live food organisms. However, other studies appear to contradict these data. Previous research $[8,65]$ showed that the live food contribution to direct digestive enzymes may be negligible. It is clear that live food organisms contribute to the digestion and assimilation process in fish larvae. However, their contribution may be in forms other than direct enzymes contribution $[66,67]$ as precursors or activators in the assimilation and absorption process.

Following the complete development of the digestive tract, juveniles quickly transform their eating habits to those of the species; this development also includes a morphological and functional adaptation. In many species studied, in fact, the development of the digestive tract is characterized by a more or less drastic increase of digestive enzymes and often by a change in the enzymatic pattern [15, 34, 68, 69]. Therefore, the assessment of the presence and level of activity of digestive enzymes may be used as a comparative indicator of the rate of development of the fish larvae, food acceptance, digestive capacity, as well as of their further survival rate [18]. 
This study was conducted on larvae and juveniles of $D$. puntazzo sampled at different time intervals (from 21 to 277 DAH) after hatching, in order to highlight the variation in digestive activity over time. All enzymatic activities studied showed a general increase in larvae and juveniles, with some exceptions.

Pepsin activity was low in the larvae, but it increased afterwards in relation with stomach development. Similarly to what reported in previous studies on this species [34], a sharp increase in pepsin-specific activity was measured between 31 and 42 DAH. This phenomenon suggested that weaning of $D$. puntazzo larvae could be started synchronously with formation of functional stomach (32 DAH). Moreover, formation of functional stomach and pepsin activity was firstly assayed $24 \mathrm{DAH}$ in D. labrax [7], $40 \mathrm{DAH}$ in $S$. aurata [5], $25 \mathrm{DAH}$ in $P$. erythrinus [70], and $30 \mathrm{DAH}$ in $P$. auriga [71].

Smith [72] reported that peptic activity in fish occurs in acid conditions ( $\mathrm{pH} \mathrm{2.0-4.0)}$ as in higher vertebrates, and is about 150 times greater than that of mammalian pepsin in its affinity for its substrate [73]. The stomach of D. puntazzo juveniles demonstrated high acid proteolytic activity and certainly this can be correlated to the high protein content in administered diet (on average $50 \%$ ). These results agree with those found in previous studies on this species [33] highlighting the role of that structure in the digestive process.

Partial hydrolysis of protein by pepsin is subsequently completed by the combined action of trypsin and chymotrypsin when food reaches the intestine. It is well known that the secretion of trypsin and chymotrypsin is known to occur in response to food ingestion and in larval pancreatic tissue most of the trypsin and chymotrypsin are present as enzymatically inactive trypsinogen and chymotrypsinogen, whereas most of the trypsin and chymotrypsin in the intestinal tract are enzymatically active [18]. In current study, trypsin was detected as early as $21 \mathrm{DAH}$ as expected for typical sparid fish [5, 70, 74]. Suzer et al. [34] reported in D. puntazzo larvae a tryptic activity present as early as on day 3 .

In juveniles levels of specific activity of trypsin are lower compared to that recorded in the whole larvae; as reported for other sparids such as $S$. aurata, D. sargus, P. eryhtrinus and for $D$. puntazzo trypsin specific activity was relatively higher during early stages and then sharply and/or slightly decline was observed coinciding with alteration of feeding regime [5, 34, 70, 75]. Also, in these species, expressions and alterations of tryptic activity could be influenced by variations of abiotical factors such as salinity [76] and $\mathrm{pH}$ [77].

Chymotrypsin activity was detected also at $21 \mathrm{DAH}$ but with levels higher than those shown for the trypsin. This activity may represent in this species the main alkaline protease secreted during the larval stage. Levels of specific activity of chymotrypsin in juveniles are lower compared to that recorded in the whole larvae and have an almost constant trend.

The variations observed in the specific activity of the alkaline proteases of $D$. puntazzo during larval development have been reported for many other species including $S$. aurata, D. sargus, and $S$. lalandi $[75,78]$. These fluctuations may be explained as a response to changes in the amount and composition of the food provided (first live prey and after commercial feed) $[5,79]$ and as change in the expression of different enzymes as a response to variations in larval metabolism. It has been suggested that alkaline proteases are responsible for protein digestion until the stomach is fully developed [80]. A decrease in the activity of the alkaline proteases may be related to an increase in the functionality of this organ $[54,81,82]$.

Elastase activity was found in larvae of $D$. puntazzo with low levels at $21 \mathrm{DAH}$; an increase of this activity was observed during the subsequent larval development. Levels found in juveniles are higher, even if they show, similar to trypsin and chymotrypsin, a decreasing trend over time. Elastase is a pancreatic serine proteinases that degrades a wilde variety of protein substrates including elastin, the insoluble and highly crosslinked protein that, together with collagen, determines the mechanical properties of connective tissue; elastase is typical of organisms that ingest animal tissues.

Elastase-like enzyme preparations were separated from the pancreatic extracts of catfisfh Parasilurus asotus [83] and of gummy shark (Mustelus antarcticus), red stingray (Dasyatis akajei), rainbow trout (Oncorhynchus mykiss), carp (Cyprinus carpio), eel (Anguilla anguilla), bluefin tuna (Thunnus thynnus), yellowtail (Seriola lalandi), sea bass (Dicentrarchus labrax) [84]. An elastase enzyme was purified from pyloric caeca of North Atlantic salmon (Salmo salar) [85].

As previously reported [31-33] qualitative and quantitative assay of glycosidases showed high glycosidase activity, an indication that $D$. puntazzo is capable of digesting carbohydrates in its diet. Digestion of carbohydrates is usually disregarded in carnivorous fish, and amylase is not considered fundamental in its digestive processes. Compared with the omnivorous fishes, amylase of the carnivorous fishes is less active [86].

It is pointed out that amylase has been found to be an integral component of the enzymatic equipment in developing larvae of carnivorous fish and also enzymatic expression and initial high levels activity of amylase in marine fish larvae do not seem to be induced by food (enriched rotifers and Artemia nauplii) and could be better explained as a result of programmed gene expression $[5,17$, 87]. However, the inductive property of this hydrolase has been described in early weaned sea bass larvae, D. labrax, fed micro-particulate diets with $12 \%$ starch [7]. As reported by some researchers, amylase is usually stimulated by polysaccharide chains, glycogen and starch; additionally food characteristics and feeding regime influenced amylase activities in fish larvae, especially in weaning time due to starch content of micro diet $[7,87,88]$.

In current study amylase activity was detected at $21 \mathrm{DAH}$ and increased $42 \mathrm{DAH}$ following the introduction of compound diet. Suzer et al. [34] reported in larval D. puntazzo two peaks for amylase activity: an abrupt increase during the early larval stages until $10 \mathrm{DAH}$ which could be genetically programmed and after a second increase coinciding with micro diet introduction at $35 \mathrm{DAH}$ due to starch content about $12 \%$. This was in agreement with results obtained 
from D. labrax [7], Pseudosciaena crocea [35] and $P$. erythrinus [70], S. ocellatus [89] larvae.

Levels of amylase activity in juveniles were higher than those found in larvae and it was possible to identify a peak at 131 days. This increase may have been induced by the starch content of the diet administered, but it is certainly related to increased ability of organisms to digest plant polysaccharides, as previously reported in this species [31-33].

Maltase is an brush border membrane enzyme involved in disaccharides digestion. In current study maltase specific activity was detected as early as 21 DAH but with very low activity levels whereas their activity during later phases of larval development increased over time, reaching in juveniles levels 30 time higher. In Dentex dentex Gisbert et al. [69] reported the maximum value of maltase specific activity at $6 \mathrm{DAH}$ and this was maintained throughout the study (50 DAH). Thus, the general pattern of maltase activity in $D$. puntazzo is similar to that already described for intestinal enzyme activities in many marine fish species [69] in which a progressive decrease in cytosolic enzyme activity is coupled with an increase of brush border membrane enzymes, characteristic of the normal maturation process of fish larval enterocytes.

High maltase activity was reported among carnivorous fish such as red seabream (Pagrus major), black seabream (Spondyliosoma cantharus) and aku (Katsuwonus pelamis) [90]. Results of the current study indicate that D. puntazzo larvae, contrary at some pelagic marine carnivorous larvae such as sea breams (Sparus spp.), Senegal sole (Solea senegalensis) and walleye Pollock (Theragta chalcegramma) $[5,91,92]$, have the capacity to digest carbohydrates also during subsequent development stage from larvae to adults. This might appear to be compatible with observations of algal grazing among marine fish larvae cultured in greenwater systems [19, 93]. It is possible that these larvae rely primarily on carbohydrates from animal prey organisms.

The presence of cellulase activity in the stomach, pyloric caeca, foregut, midgut and hindgut of $D$. puntazzo juveniles and adults was previously reported [33]; cellulase occurs in few vertebrates, including omnivorous and detritivorous fishes, and where it occurs, the source is usually traced to the micro flora inhabiting their guts [94, 95]. Others authors [96] examined digestive enzyme activities, luminal carbohydrate profiles, and gastrointestinal fermentation in xylivorous and detritivorous loricariids catfishes to determine if these animals were capable of digesting a diet rich in refractory polysaccharides, and whether they were reliant on an endosymbiotic community to do so. The results showed that wood-eating catfishes are not reliant upon endosymbionts to digest refractory polysaccharides [96].

In rearing conditions the cellulose is present as component of several vegetable foodstuffs (soybean meal, corn gluten and wheat bran) or as diet binders (sodium carboxymethylcellulose, starch, wheat gluten).

In current study cellulase specific activity was detected at $21 \mathrm{DAH}$ and decreased after $31 \mathrm{DAH}$. This pattern seems to depend by the incorporation of exogenous enzymes present in the live prey administered in this stage of larval development and that can justify the rapid decrease of cellulase activity at the introduction of compound diet. Levels of cellulase activity in juveniles were lower than those found in larvae and remain almost constant over time, implying that these levels did not seem related to the amount of cellulose in the compound diet, which rose from $1.0 \%$ to $2.4 \%$ in the last sampling period.

The content of fats is critical for animal species. Usually, carnivorous fish consume fat-rich food, and the occurrence of lipase in their digestive tract is justified [97]. It is well known that lipase catalyses the breakdown of triacylglycerol first to diacylglycerol and then to monoacylglycerol. It is produced mainly in the pancreas and is thought to play a relatively minor role in lipid digestion in fishes. It seems that direct response of lipase activity to its substrate, triglycerides, suggested that maximal capacity of lipase synthesis are triglycerides in the diet.

Lipase activity was detected in all the regions of the gut in D. puntazzo adults [33], especially in the neutral-alkaline gut regions, indicating a uniform distribution in the entire gut system which was similarly observed in several teleosts [98].

Alvarez Gonzales et al. [1] reported that lipase activity was detected just after mouth opening and coinciding with the onset of exogenous feeding, and it gradually increased until 15 days after hatching. Several authors have noted that activities of enzymes involved in lipid digestion were detected in first feeding marine fish larvae and the expression of these enzymes increased with development [99-102]. In some cases, high lipase activities were detected at early stages and then decreased during larval development [16], which might be attributed to changes in food quality and quantity [79]. In common dentex [69] lipase was detected from hatching and progressively increased during larval ontogeny, peaking at $35 \mathrm{DAH}$ and decreasing after then coinciding with the weaning of larvae into inert diet.

In this study, lipase specific activity was detected on day 21 and progressively increased with growth to $42 \mathrm{DAH}$ after compound diet introduction which could be related with triglyceride content of compound diet. Levels of lipase activity in juveniles were higher than those found in larvae although there was a decrease in activity levels up to 131 days. This results are in agreement with Suzer et al. [34] who described in $D$. puntazzo larvae an increase in lipase activity to $20 \mathrm{DAH}$, then a slight decrease and a second increase from $35 \mathrm{DAH}$, after microdiet introduction. Similar lipase activities were found in some species such as $P$. erythrinus [70], D. sargus [75], Seriola lalandi [78], S. ocellatus [89], and S. senegalensis [92] larvae.

Our results didn't show an inductive character of lipases, since in juveniles the activity levels were almost constant even if varied the fat content of compound diet (from $7.0 \%$ to $20 \%$ ). Indeed it is known that regulation of lipolytic enzyme synthesis seems to be more efficient in young larvae, explaining why larval growth is as dependent on dietary lipid levels as pointed out by Cahu and Zambonino Infante [88].

\section{CONCLUSIONS}

This study presents data on digestive functions in Diplodus puntazzo larvae and juveniles and constitutes an ulterior step in the development of a compound diet suitable for the larvae of this species. The rapid changes in the 
digestive activities of $D$. puntazzo larvae supported the existence of well established induction and regulation digestive mechanisms. This might reflect an increase in the programmed genetic expression and production of different proteins associated with these changes during the development of the larvae. Present results also confirm that $D$. puntazzo larvae have complete digestive enzymatic equipment that increased during larval ontogeny and enable larvae to digest and absorb nutrients contained in live preys once exogenous feeding occurred. Furthermore, the weaning onto commercial feeds around $30 \mathrm{DAH}$ corresponds to time in which $D$. puntazzo larvae have achieved maturation of their digestive functions.

As previously observed [32, 33] the occurrence of various glycosidases, proteases and lipases in D. puntazzo larvae and juveniles is correlated with omnivorous feeding habits of the species [103, 104]. The increase in pepsin and glycosidase activity in juveniles is correlated to a decrease in proteolytic alkaline pancreatic enzymes between 40 and 60 days, such as chymotrypsin and elastase, but also in lipase, indicating a change in the digestive physiology of $D$. puntazzo early juveniles and the full achievement of an adult-type digestion.

Moreover, it can be determined that the patterns of activity of the primary digestive enzymes involved in the digestive processes of $D$. puntazzo larvae and juveniles indicate early functional development of this system and suggest that this species is a good candidate for Mediterranean aquaculture using the compound diet. However, an ulterior approach should be used to evaluate the effects of artificial foods with different wording on the growth performance and survival of this species in rearing.

\section{ACKNOWLEDGEMENTS}

This work was supported by European Structural Funds Multiregional Operational Program 2000-2006. We also thank Dr. Vito Balsamo for allowing the collection of samples within the fish farm, and Mr. Salvatore Manzella for his cooperation during collection and transport of samples.

\section{REFERENCES}

[1] Alvarez-Gonzàlez CA, Cervantes-Trujano M, Tovar-Ramìrez D, et al. Development of digestive enzymes in California halibut Paralichthys californicus larvae. Fish Physiol Biochem 2006; 31: 83-93.

[2] Phillips AM Jr. Nutrition, digestion and energy utilization. In: Hoar WS, Randall DJ, Eds. Fish Physiology. New York: Academic Press 1969; pp. 391-32.

[3] Buchet V, Zambonino Infante JL, Cahu C. Variation in activities of some digestive enzymes during larval development of Scianops ocellatus. In: Creswell L, Harache Y, Eds. The Island Aquaculture and Tropical Aquaculture. Oostende, Belgium: European Aquaculture Society 1997; pp. 55-6.

[4] Holt GJ. Feeding larval red drum on microparticulate diets in a closed recirculating water system. J World Aquacult Soc 1993; 24: 225-30.

[5] Moyano FJ, Dìaz M, Alarcòn FJ, Sarasquete MC. Characterization of digestive enzyme activity during development of gilthead seabream (Sparus aurata). Fish Physiol Biochem 1996; 15: 121-30.

[6] Sarasquete MC, Polo A, Conzàlez de Canales ML. A histochemical and immnohistochemical study of digestive enzymes and hormones during the larval development of Sparus aurata L. Histochem J 1993; $24: 337-44$.
[7] Zambonino Infante JL, Cahu CL. Development and response to a diet change of some digestive enzymes in sea bass (Dicentrarchus labrax) larvae. Fish Physiol Biochem 1994; 12: 399-08.

[8] Zambonino Infante JL, Cahu CL, Péres A, Quazuguel P, Le Gall MM. Sea bass (Dicentrarchus labrax) larvae fed different Artemia rations: growth, pancreas enzymatic response and development of digestive functions. Aquaculture 1996; 139: 129-38.

[9] Clark J, Murray KR, Stark JR. Protease development in Dover sole (Solea solea L.). Aquaculture 1986; 53: 253-62.

[10] Cousin JBC, Baudin-Laurencin F, Gabaudan J. Ontogeny of enzymatic activities in fed and fasting turbot, Scophthalmus maximus L. J Fish Biol 1987; 30: 15-33.

[11] Munilla-Moràn JR, Stark R, Barbour A. The role of exogenous enzymes in the digestion in culture of turbot larvae (Scophthalmus maximus L). Aquaculture 1990; 88: 337-50.

[12] Hoehne-Reitan K, Kjorsvik E, Gjellesvik DR. Development of bile salt-dependent lipase in larval turbot. J Fish Biol 2001; 58: 737-45.

[13] Ribeiro L, Zambonino Infante JL, Cahu C, Dinis MT. Development of digestive enzymes in larvae of Solea senegalensis, Kaup 1858. Aquaculture 1999; 179: 465-73.

[14] Kurokawa T, Suzuki T. Formation of a diffuse pancreas and the development of digestive enzymes synthesis in larvae of Japanese flounder Paralichthys olivaceus. Aquaculture 1996; 141: 267-76.

[15] Segner H, Rosch R, Schmidt H, Von Poeppinghausen K. Digestive enzymes in larval Coregonus lavaretus L. J Fish Biol 1989; 35: 249-63.

[16] Walford J, Lam TJ. Development of digestive tract and proteolytic enzyme activity in seabass (Lates calcarifer) larvae and juveniles. Aquaculture 1993; 109: 187-05.

[17] Zambonino-Infante JL, Cahu CL. Ontogeny of the gastrointestinal tract of marine fish larvae. Comp Biochem Physiol 2001; 130: 47787.

[18] Ueberschar B. Measurement of proteolytic enzyme activity: significance and application in larval fish research. In: Walther BT, Fuhn HJ, Eds. Physiological and Biochemical Aspects of Fish Development. Norway: University of Bergen 1993.

[19] Cahu C, Zambonino-Infante JL, Escaffre AM, Bergot P, Kaushik S. Preliminary results on sea bass Dicentrarchus labrax larvae rearing with compound diet from first feeding, comparison with carp Cyprinus carpio larvae. Aquaculture 1998; 169: 1-7.

[20] Yùfera $M$, Fernàndez-Dìaz $C$, Pascual E. A highly efficient microencapsulated food for rearing early larvae of marine fish. Aquaculture 1999; 177: 249-56.

[21] Cahu C, Zambonino Infante JL, Barbosa V. Effect of dietary phospholipid level and phospholipid: neutral lipid value on the development of sea bass (Dicentrarchus labrax) larvae fed a compound diet. Br J Nutr 2003; 90: 21-8.

[22] Marangos C. Larviculture of the sheepshead bream, Puntazzo puntazzo Gmelin 1789 Pisces. Sparidae. A workshop on Diversification in Aquaculture, Cyprus. Cah Opt Médit 1995; 16: 41-6.

[23] Boglione C, Giganti M, Selm C, Cataudella S. Morphoecology in larval fin fish: a new candidate species for aquaculture, Diplodus puntazzo (Sparidae). Aquacult Int 2003; 11: 17-41.

[24] Papandroulakis N, Kentouri M, Maingot E, Divanach P Mesocosm: a reliable technology for larval rearing of Diplodus puntazzo and Diplodus sargus sargus. Aquacult Int 2004; 12: 34555.

[25] Bauchot ML, Hureau JC. Sparidae. In: Quero JC, Hureau JC, Karrer C, Post A, Saldanha L, Eds. Check-list of the Fishes of the EasternTropical Atlantic (CLOFETA). Lisbon: JNICT 1990; Vol. II, pp. 1-798.

[26] Micale V, Perdichizzi F, Basciano G. Aspects of the reproductive biology of the sharpsnout sea bream Diplodus puntazzo (Cetti, 1777). Gametogenesis and gonadal cycle in the captivity during the third year of life. Aquaculture 1996; 140: 281-91.

[27] Atienza MT, Chatzifotis S, Divanach P. Macronutrient selection by sharp snout seabream (Diplodus puntazzo). Aquaculture 2004; 232: 481-91.

[28] Hernández MD, Martínez FJ, García GB. Sensory evaluation of farmed sharpsnout seabream (Diplodus puntazzo). Aquacult Int 2001; 9: 519-29.

[29] Vivas M, Rubio VC, Sánchez-Vázquez FJ, Mena C, García GB, Madrid JA. Dietary self-selection in sharpsnout seabream (Diplodus puntazzo) fed paired macronutrient feeds and challenged with protein dilution. Aquaculture 2006; 251: 430-7. 
[30] Favaloro E, Lopiano L, Mazzola A. Rearing of sharpsnout sea bream (Diplodus puntazzo, Cetti 1777) in a Mediterranean fish farm: monoculture versus polyculture. Aquacult Res 2002; 33: 13740 .

[31] Savona B. Dati preliminari sulle attività digestive in Diplodus puntazzo (Cetti, 1777). Biol Mar Medit 1999; 6 (1): 340-2.

[32] Savona B, Tramati C, Sarà G. Andamento temporale delle attività digestive in Diplodus puntazzo (Cetti, 1777). Biol Mar Medit 2000; 7(2): 637-40.

[33] Tramati C, Savona B, Mazzola A. A study of the pattern of digestive enzymes in Diplodus puntazzo (Cetti, 1777) (Osteichthyes, Sparidae): evidence for the definition of nutritional protocols. Aquacult Int 2005; 13: 89-95.

[34] Suzer C, Aktülün S, Çoban D, et al. Digestive enzyme activities in larvae of sharpsnout seabream (Diplodus puntazzo). Comp Biochem Physiol Part A 2007; 148: 470-7.

[35] Ma H, Cahu C, Zambonino Infante JL, et al. Activities of selected digestive enzymes during larval development of large yellow croacker (Pseudosciaena crocea). Aquaculture 2005; 245: 239-48.

[36] Bradford MM. A rapid and sensitive method for the quantitation of microgram quantities of protein utilizing the principle of protein dye binding. Anal Biochem 1976; 72: 248-54.

[37] Anson ML. The estimation of pepsin, trypsin, papain and cathepsin with haemoglobin. J Gen Physiol 1938; 22: 79-89.

[38] Rick W. Pepsin. In: Bergmeyer HU, Ed. Methods of Enzymatic analysis. New York: Academic Press 1974; vol. 2: pp. 1046-52.

[39] Hummel BCW. A modified spectrophotometric determination of chymotrypsin, trypsin and thrombin. Can J Bioch Physiol 1959; 37 : 1393-9.

[40] Rick W. Trypsin. In: Bergmeyer HU, Ed. Methods of Enzymatic analysis. New York: Academic Press 1974; vol. 2: pp. 1021-4.

[41] Rick W. Chymotrypsin. In: Bergmeyer HU, Ed. Methods of Enzymatic analysis. New York: Academic Press 1974; vol. 2: pp. 1009-12.

[42] Sachar LA, Winter KK, Sicher N, Fraukel S. Photometric method for estimation of elastase activity. Proc Soc Exp Biol Med 1955; 90: 323-6.

[43] Bernfeld P. Amylases, $\alpha$ and $\beta$. In: Colowick SP, Kaplan NO, Eds. Methods in Enzymology. New York: Academic Press 1955; vol. I: pp. 149-58.

[44] Rick W. $\alpha$-Amylase. In: Bergmeyer HU, Ed. Methods of Enzymatic analysis. New York: Academic Press 1974; vol. 2: pp. 885-90.

[45] Dahlqvist A. Disaccharidases. In: Bergmeyer HU, Ed. Methods of Enzymatic analysis. New York: Academic Press 1974; vol. 2: pp. 916-22.

[46] Pettersson G, Porath J. A cellulolytic enzyme from Penicillum notatum. In: Colowick SP, Kaplan NO, Eds. Methods in Enzymology. New York: Academic Press 1966; vol. VIII: pp. 6037.

[47] Tietz NW, Fiereck EA. A specific method for serum lipase determination. Clin Chem Acta 1966; 13: 352-8.

[48] Underwood AJ. Experiments in ecology: their logical design and interpretation using analysis of variance. Cambridge: Cambridge University Press 1997.

[49] Dement'eva MA. Anatomical-histological features of digestive tract in the rainbow trout at the early phases of ontogenesis. Izv GosNIORKh 1976; 22: 876-84.

[50] Il'ina ID. Physiologobiochemical Aspects of Protein Nutrition of Carp Larvae. Cand. Sci. (Biol.) Moscow: Dissertation 1986.

[51] Kuz'mina VV, Gel'man AM. Specific features of digestive function development in fish. Vopr Ikhtiol 1998; 1: 113-22.

[52] Alliot E, Pastoureaud A, Trellu J. Evolution des activities enzymatiques dans le tractus digestif au cour de la vie larvaire de la sole. Variations des proteinogrammes et des zymogrammes. Biochem Syst Ecol 1980; 8: 441-5.

[53] Baragi V, Lovell RT. Digestive enzyme activities in stripped bass from first feeding through larval development. Trans Am Fish Soc 1986; 115: 478-84.

[54] Baglole CJ, Goff GP, Wright GM. Distribution and ontogeny of digestive enzymes in larval yellowtail and winter flounder. J Fish Biol 1998; 53: 767-84.

[55] Tanaka M. Studies on the structure and function of the digestive system in teleost larvae. Part 5: Epithelial changes in the posterior gut and protein ingestion. Jpn J Ichthyol 1972; 19: 172-80.
[56] Segner H, Rosch R, Verreth J, Witt U. Larval nutritional physiology: Studies with Clarias gariepinus, Coregonus lavaretus and Scophthalmus maximus. J World Aquacult Soc 1993; 24: 12134.

[57] Perez-Casanova JC, Murray HM, Gallant JW. Development of the digestive capacity in larvae of haddock (Melanogrammus aeglefinus) and Atlantic cod (Gadus morhua). Aquaculture 2006; 251 (2-4): 377-01.

[58] Sveinsdottir H, Thorarensen H, Gudmundsdottir A. Involvement of trypsin and chymotrypsin activities in Atlantic cod (Gadus morhua) embryogenesis. Aquaculture 2006; 260 (1-4): 307-14.

[59] Korzhuev PA, Sharkova LB. On Specific Features of Digestion in Caspian Sturgeon, Obmen veshchestv ibiokhimiya ryb (Metabolism and Biochemistry of Fish), Moscow 1967; pp. 205-8.

[60] Volkova IV. Activities of Digestive Enzymes in Plant-Eating Fish at Early Phases of Ontogenesis. Cand Sci (Biol.) Astrakhan: Dissertation 1999.

[61] Jancarik A. Die verdauung der hauptnaehrstoffe biem karpfen. Z Fisch Deren Hilfswiss 1964; 12: 602-84.

[62] Dabrowski K. The feeding of fish larvae: present "state of the art" and perspectives. Reprod Nutr Dev 1984; 24: 807-33.

[63] Lauff M, Hofer R. Proteolytic enzymes in fish development and the importance of dietary enzymes. Aquaculture 1984; 37: 335-46.

[64] Kolkovski S, Tandler A, Kissil GW, Gertler A. The effect of dietary exogenous digestive enzymes on ingestion, assimilation, growth and survival of gilthead seabream larvae. Fish Physiol Biochem 1993; 12: 203-9.

[65] Cahu C, Zambonino-Infante JL. Is the digestive capacity of marine fish larvae sufficient for compound diet feeding? Aquacult Int 1997; 5: 151-61.

[66] Kolkovski S, Arieli A, Tandler A. Visual and chemical cues stimulate microdiet ingestion in gilthead seabream, Sparus aurata, larvae. Aquacult Int 1997; 5: 527-36.

[67] Koven WM, Parra G, Kolkovski S, Tandler A. The effect of dietary phosphotidylcholine and its constituent fatty acids on microdiet ingestion and fatty acid absorption rate in gilthead seabream Sparus aurata larvae. Aquacult Nutr 1998; 4: 39-45.

[68] Zambonino Infante JL, Cahu CL. Development and response to a diet change of some digestive enzymes in sea bass (Dicentrarchus labrax) larvae. Fish Physiol Biochem 1994; 12: 399-408.

[69] Gisbert E, Giménez G, Fernández I, Kotzamanis Y, Estévez A. Development of digestive enzymes in common dentex Dentex dentex during early ontogeny. Aquaculture 2009; 287: 381-7.

[70] Suzer C, Fırat K, Saka Ş. Ontogenic development of the digestive enzymes in common pandora, Pagellus erythrinus, L. larvae. Aquacult Res 2006; 37: 1565-71.

[71] Sánchez-Amaya MI, Ortiz-Delgado JB, García-López Á, Cárdenas S, Sarasquete C. Larval ontogeny of red banded seabream Pagrus auriga Valenciennes, 1843 with special reference to the digestive system. A histological and histochemical approach. Aquaculture 2007; 263: 259-79.

[72] Smith LS. Digestive functions in teleost fishes. In: Halver JE, Ed. Fish nutrition. London: Academic Press 1989; pp. 331-21.

[73] Ananichev AB. Digestive enzymes of fish and seasonal change in their activity. Biokhimiya 1959; 24: 1033-40.

[74] Moyano FJ, Barros AM, Prieto A, Cañavate JP, Cárdenas S. Evaluación de la ontogenia de enzimas digestivas en larvas de hurta, Pagrus auriga (Pisces: Sparidae). Rev Aquat Sci 2005; 22: 39-47.

[75] Cara JB, Moyano FJ, Cárdenas S, Fernández-Díaz C, Yúfera M. Assessment of digestive enzyme activities during larval development of white bream. J Fish Biol 2003; 63: 48-58.

[76] Moutou KA, Panagiotaki P, Mamuris Z. Effects of salinity on digestive protease activity in the euryhaline sparid Sparus aurata L.: a preliminary study. Aquacult Res 2004; 35: 912-4.

[77] Deguara S, Jauncey K, Agius C. Enzyme activities and $\mathrm{pH}$ variations in the digestive tract of gilthead sea bream. J Fish Biol 2003; 62: 1033-43.

[78] Chen BN, Qin JG, Kumar SM, Hutchinson WG, Clarke SM. Ontogenetic development of digestive enzymes in yellowtail kingfish Seriola lalandi larvae. Aquaculture 2006; 260: 264-71.

[79] Morais S, Lacuisse M, Conceição LEC, Dinis MT, Rønnestad I. Ontogeny of the digestive capacity of Senegalese sole (Solea senegalensis), with respect to digestion, absorption and metabolism of amino acids from Artemia. Mar Biol 2004; 145: 243-50. 
[80] Ribeiro L, Zambonino-Infante JL, Cahu CL, Dinos MT. Digestive enzymes profile of Solea senegalensis post larvae fed Artemia and a compound diet. Fish Physiol Biochem 2002; 27: 61-9.

[81] Cahu CL, Zambonino-Infante JL. Early weaning of sea bass (Dicentrarchus labrax) larvae with a compound diet: effect on digestive enzymes. Comp Biochem Physiol 1994; 109A: 213-22.

[82] Kvåle A, Mangor-Jensen A, Moren M, Espe M, Hamre K. Development and characterisation of some intestinal enzymes in Atlantic cod (Gadus morhua L.) and Atlantic halibut (Hippoglossus hippoglossus L.) larvae. Aquaculture 2007; 264: 457-68.

[83] Yoshinaka R, Tanaka H, Sato M, Ikeda S. Characterization of catfish pancreatic elastase. Bull Jpn Soc Sci Fish 1983; 49 (4): $637-$ 42.

[84] Yoshinaka R, Sato M, Tanaka H, Ikeda S. Distribution of pancreatic elastase and metalloproteinase in several species of fish. Comp Biochem Physiol B 1985; 80 (2): 227-33.

[85] Berglund GI, Willassen NP, Hordwick A, Smalås O. Structure of native pancreatic elastase from north Atlantic salmon at $1.61 \AA$ resolution. Acta Cryst 1995; D51: 925-37.

[86] Sabapathy U, Teo LH. A quantitative study of some digestive enzymes in the rabbitfish, Siganus canaliculatus and the sea bass, Lates calcalifer. J Fish Biol 1993; 42 (4): 595-02.

[87] Péres A, Zambonino Infante JL, Cahu C. Dietary regulation of activities and mRNA levels of trypsin and amylase in sea bass (Dicentrarchus labrax) larvae. Fish Physiol Biochem 1998; 19: 145-52.

[88] Cahu C, Zambonino Infante JL. Substitution of live food by formulated diets in marine fish larvae. Aquaculture 2001; 200: 16180 .

[89] Lazo JP, Dinis MT, Holt GJ, Faulk C, Arnold RA. Cofeeding microparticulate diets with algae: toward eliminating the need of zooplankton at first feeding in larval red drum (Sciaenops ocellatus). Aquaculture 2000; 188: 339-51.

[90] Kawai SI. Studies on the digestive enzymes of fishes with special reference to carbohydrases. PhD. Depart. Of Fisheries, Faculty of Agriculture, Kyoto University: Dissertation 1972; p. 44.

[91] Oozeki Y, Bailey KM. Ontogenetic development of digestive enzyme activities in larval walleye pollock, Theragra chalcogramma. Mar Biol 1995; 122: 177-86.

[92] Martínez MI, Moyano FJ, Fernández-Díaz C, Yúfera M. Digestive enzyme activity during larval development of the Senegal sole (Solea senegalensis). Fish Physiol Biochem 1999; 21: 317-23.
[93] Danilowicz BS, Brown CL. Rearing methods for two damslefish species: Dascyllus albisella (Gill) and D. aruanus (L.). Aquaculture 2002; 106: 141-9.

[94] Fagbenro OA, Adedire CO, Owoseeni EA, Ayotunde EO. Studies on the biology and aquaculture potential of feral catfish Heterobranchus bidorsalis Geoffroy St. Hilaire (1809) (Clariidae). Trop Zool 1993; 6: 67-79.

[95] Nelson JA, Wubah D, Whitmer M, Johnson E, Stewart D. Woodeating catfishes of the genus Panaque: gut microflora and cellulolytic enzyme activities. J Fish Biol 1999; 54: 1069-82.

[96] German DP, Bittong RA. Digestive enzyme activities and gastrointestinal fermentation in wood-eating catfishes. J Comp Physiol B 2009; 179: 1025-42.

[97] Chakrabarti I, Gani MDA, Chaki KK, Sur R, Misra KK. Digestive enzymes in 11 freshwater teleost fish species in relation to food habit and niche segregation. Comp Biochem Physiol A 1995; 112: 167-77.

[98] Swarup C, Goel KA. Histochemical study of the activity of lipase in the digestive system of some teleost fishes. Acta Histochem 1975; 54: 10-5.

[99] Ozkizilcik S, Chu F-LE, Place AR. Ontogenetic changes of lipolytic enzymes in striped bass (Morone saxatilis). Comp Biochem Physiol 1996; 113B: 631-7.

[100] Gawlicka A, Parent B, Horn MH, Ross N, Opstad I, Torrinsen OJ. Activity of digestive enzymes in yolk-sac larvae of Atlantic halibut (Hippoglossus hippoglossus): indication of readiness for first feeding. Aquaculture 2000; 184: 303-14.

[101] Izquierdo MS, Socorro J, Arantzamendi L, Hernández-Cruz CM. Recent advances in lipid nutrition in fish larvae. Fish Physiol Biochem 2000; 22: 97-107.

[102] Srivastava AS, Kurokawa T, Suzuki T. mRNA expression of pancreatic enzyme precursors and estimation of protein digestibility in first feeding larvae of Japanese flounder Paralichthys olivaceus. Comp Biochem Physiol 2002; 132: 629-35.

[103] Ceccarelli R, Fresi E, Plastina N, Scardi M. Comportamento alimentare degli stadi giovanili di Diplodus puntazzo (Gm.) dell'Isola d'Ischia. Nova Thalassia 1983; 6: 503-9.

[104] Mirto S, Scilipoti D, Lopiano L, Badalamenti F, Mazzola A. Primi dati sul ritmo alimentare giornaliero di tre specie ittiche nello Stagnone di Marsala (Sicilia Occidentale). Biol Mar Medit 1994; 1 (1): 335-6. 